\title{
Divinity on Sale: Investigating Religious Symbolism in Commercials
}

Muhammad Awais Memon ${ }^{1}$

Dr. Mustaghis-ur-Rahman ${ }^{2}$

\begin{abstract}
This research study explores the practice of using religious symbolism and holy iconography in marketing messages and promotional communications. To incite a desire in audience for purchase of certain items, religion is being used as a tool to convert possible audiences into buyers and consumers. This reveals current standing of creed and religion in our society which requires a thorough analysis of the implications of using religious symbolism for commercial purposes. To this end, the study investigates relationship between religion, sacred imagery and attitude of consumers towards religious iconography. After collecting data from sample of 150 undergraduate and graduate students various relationships were tested and it was found that significant relationship exists between religious symbolism and customer preference for commercials.
\end{abstract}

Keywords: Advertisements, consumer behavior, culture, imagery, marketing messages, religion

\section{Introduction}

In marketing communications, creating controversy is the easiest and economical way to grab attention and seek recognition from consumers. Buyers and consumers respond to such advertisements but sometimes brands surpass all the boundaries, going to the outrageous extreme of mixing religion in commercials such as United Colors of Benetton, Axe deodorant, Red Bull, Diesel, Dolce and Gabbana and many more. It is a common notion amongst shoppers that marketers can do anything to entice shoppers (Moore 2013). Religion and its associated cues are no exception to marketers for selling their products (Story 2007; Gökariksel \& Secor 2010).

It is evident that religion has been commercialized to sell plethora of products ranging from high tech gadgets to beauty and personal grooming products. Religious messages, imagery and professions of faith are used to reach target audience and sell the wares. Inclusion of religious symbolism can be traced back to the first legislative drafts as incorporated in freedom of religion that founding fathers deemed necessary to pave the way for democracy in society. It is a fact that religion, also classified as a belief system, plays a pivotal role in influencing and shaping social and consumer behavior. It is in fact religious inclination that nurtures mindset of the people and influences their life style, interact, behave and associate with others in the social order. Impact of religion on social norms and values is well documented and reflected. Review of related literature clearly indicates that religion impacts upon marketing communications particularly promotional mix.

Embodiment of religious symbolism is deemed necessary for obtaining desired behavior by certain people [read sellers] (Geertz 1973). Multiple religious symbols with meanings associated with supernatural are imbued in lives of many people. Such sacred symbols have deep meaning and presence. For example, Harmain Sharifain is the most important symbol of Islamic heritage and faith; similarly for Christians, the cross symbolizes a sacred sacrifice and theological triumph.

${ }^{1}$ Muhammad Awais Memon is Lecturer at Indus University, Karachi, 786.muhammadawais@gmail.com

${ }^{2}$ Dr. Mustaghis-ur-Rahman is Professor at SZABIST, Karachi, mustaghis@szabist.edu.pk

\begin{tabular}{llll|l}
\hline JISR-MSSE & Volume 10 & Number 2 & July 2012 & 33
\end{tabular}


The point is presence of any such symbols and imagery in marketing communications is a constant call of reminder for the followers of a particular religion (The Charlotte Observer, March 31, 1991). Mallia (2009) argued that religious symbolism in advertisements helps brands cut clutter in highly competitive market overcrowded with products.

Depending on the magnitude of faith, a person's attitude towards religious symbolism and imagery varies. Magnitude and strength of a faith is proclaimed by religious dogmatism or religiosity (Giuseppe 1971). Religiosity is positively correlated with the affiliation level and meaning a religion has in one's life. Concrete religious imagery and symbolism is, therefore, more meaningful to a person having greater religious inclination. Solomon in 1983 argued that a consumer's objective reality is influenced by religious symbolism surrounding such products. Objective reality is coming in contact with such consumption products and services. Consumers develop attitude and relationship with products and their advertisements keeping in mind religious and cultural nodes (Gottdiener 1985). Mohandass (2006) found that religious symbolism in advertisements has influence on consumers' attitude.

Likeness of the advertisements and favorable attitude for the advertised brand depends on the creativity and explicit/implicit use of religious imagery (Mohandass 2006). Earlier, literature showed that religious symbolism in advertisement up sets many buyers and spawns suspicion in the minds of buyer as if the brand is trying to hide and costume some glitches by employing religious engagement. Product or service that is worth selling is sold or purchased; if religion is imbued it excites few at the cost of many current and prospective buyers. Although the magnitude of religious imagery and messages used in advertisements is a new trend, marketing the faith is old phenomenon (Finke \& Iannaccone 1993; Moore 1994). Declaring a religion-free state means that citizens would be free to practice any faith and different faiths would vie for promulgating their version of belief and values. Marketers and advertisers believe that consumers around the world share similar need for products and services and that international market is growing to be more homogenous as result of globalization. Behemoth expansion of the international media and development of high tech sophisticated devices have allowed marketers to the design international campaigns. According to Levitt (1983) global target audience, therefore, can be tapped with congruent messages. One of the reasons for this is intense competition and marketers are vying for more wallet share than their competitors (Kaplan 1994).

Before designing standard messages, advertisers consider social and cultural differences of consumers (Kaplan 1994). Success of these commercials and messages depends on their alignment with local tastes and preferences. Consumer buying decisions are influenced by social, cultural, psychological factors and personal attributes. World of consumers offer a web of meaning which marketers must comprehend as products represent many things farther than their functional benefits (Levy 1959 \& 1989). Cultural symbolism has been the focus of consumer research to intrude minds and souls of buyers. Marketers and advertisers create such associations through different sources and settings in which products are consumed.

Consumer attitude towards products and their advertisements depends upon their cultural associations. Culture, subculture and social class are key factors in marketing of products and services. Gottdiener (1985) found that symbols and cultural imagery are important factors in influencing purchase decisions. Herm (2011) suggested that in fast moving consumer goods shoppers are more inclined to implicit cues such as religious iconography as they glance through shelves. Associating a brand with rich cultural and religious traditions is likely to stimulate its image and buying probability. Hence, it is of paramount importance to many marketers and advertisers to explore marketing of theological themes, religious imagery and spiritual symbols; the perception of consumers about mixing religion with marketing. This research study investigates

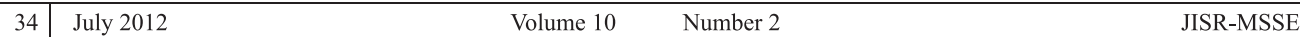


benefits and repercussions of the usage of religious symbolism in the market that has strong religious and cultural traditions.

A great sign showing the direction of where theological marketing is heading is indicated by the fact that Walmart sold products and services of more than $\$ 1$ billion having religious content and imagery. Theological imagery and symbolism may appeal to customers but at the same time makes many customers unhappy and offensive towards advertisement and brand. Now, the dimensions of religious marketing has reached the point where it seeks attention of researchers to probe whether the religious marketing is a beneficial business approach or it is otherwise in the larger business context.

\section{Literature Review}

Marketers and advertisers believe that consumers around the world share similar need for products and services, and that international market is growing to be more homogenous as result of globalization. As globalization has helped shrink boundaries and change the rules of business, goods and services can be traded across geographical distances with more ease and comfort than ever before in history. This has a profound impact on culture and habits of individuals and their buying behavior. Due to globalization of cultures, convergence of informatics, media, technology, and interdependence for exotic products and services: marketing managers and advertisers are able to find a shared turf for global target audiences (Gupta 2011). In developed economies, advertisements and communications add vibrancy to the business environment but for the others this seems to be a new occurrence. Research in global advertisements show that national culture shapes the ways buyers respond to marketing messages and commercials. Logos, symbols and brand archetypes are understood by global audience on common nodes but with different local interpretations. Most important component that constitutes effectiveness of advertisements is likeness or dislikeness. Research confirms that liked advertisements incite consumer's intension to buy the advertised product or services upsurges. Likeness of advertisements is of paramount importance to advertisers as a tool to gauge advertisement's effectiveness. There are a number of parameters to gauge likeability of advertisements. This includes convincing, creative, entertaining, relevant, and pleasant. Similarly, dimensions of dislikeness are irritating, disgusting, confusing, alienating and impolite.

Prabhaker and Alwit (1994) propound that marketers and advertisers must have cognizance of why customers show aversion aptitude for particular advertisements in order to solve this fiasco of hatred towards messages. Such advertisements truncate the favorable attitude of the brand being advertised (Aaker \& Stayman 1990; Biel \& Bridgwater 1990; Franzen 1994). On the contrary, few researchers have postulated theories which support negative perspective for advertisements. The impact of culture on likeness and dislikeness of advertisements amongst audiences across different cultures and countries is a well-researched phenomenon. Culture is defined as "the interactive aggregate of common characteristics that influences a group's response to its environment" (Hofstede 1980, p. 19). Successful marketing strategies take into account cultural, sub-cultural and social perspectives in order to better serve chosen markets and local consumer behavior. Therefore, understanding cross cultures has been at the heart of marketing communications particularly differences in advertising content (Abernethy \& Franke 1996). Many studies have been focused on finding similarities and differences in advertising expressions across different cultures. Marketing communications and advertising expressions tailored at particular group are likely to produce favorable attitude and reward for advertisers (Zhang \& Gelb 1996). Symbolic Interaction Theory suggests that humans learn from messages in their environment by giving these cues meanings and behavior (Burbank \& Martins 2009). Religious belief and values is another important variable in defining advertising content.

\begin{tabular}{llll|l}
\hline JISR-MSSE & Volume 10 & Number 2 & July 2012 & 35
\end{tabular}


Advertisers try to make advertisements in alignment with cultural values. Many researchers argue that it is very difficult to standardize and regulate advertisements and promotion campaigns in different markets; the reason is difference in culture, values, language, music and traditions (Geier 1986; Hornik 1980; Mueller 1992). However, Boddewyn (1982); Boote (1982); Britt (1987); Hite and Fraser (1988) argued that advertisements and marketing communications must adapt to cultural values and norms to avoid triggering of negative and offensive attitude. Luqmani, Yavas and Quraeshi (1987) compared American culture with Arab culture in the Muslim world on three dimensions i.e., religious manifestations, Hofstedes level of individualism and cultural context. Arab culture is enriched in Islamic religious philosophy and reasoning and consensus among the Islamic scholars are considered two important pillars in determining domain and nature of advertising content and expression (Coulson 1964). Islamic values and philosophy influenced by Shariah impacts upon the nature of advertising content. It is; however, important to note that people indirectly influence advertising expressions and content only through copywriters and directors. Shariah restricts sellers not to make promises which they cannot deliver. Men and women are expected to appear modestly and do not show their private parts and lower their gaze. Although these Quranic injunctions might not be followed strictly, there is public expectation of modesty and advertisers should not deviate from such expectations. Luqmani, Yavas and Quraeshi (1987) suggest that religious morals require women to wrap their bodies, therefore, western advertisements must be modified. As there are fewer restrictions in American culture, women are showcased frequently and openly. Muslims share collectivist culture using comparative advertisements for selling products. It may result in gaining hatred. Harrell (1986) suggests that religion has major implications on consumer behavior. It directly influences consumption and consumption choices. For instance, Buddhism is not based on holy writings and religious dogmatism, therefore, Buddhist consumers tend to be less materialistic than those of followers of other religions. Reflection of austere life and spiritual tendency is evident in their behavior to buy products and services.

People belonging to Catholic Church tend to prefer products and services that are more popular and consistent with religious conformity. Based on the Hindu beliefs and practices, it is important for Hindus to follow norms and values of caste system and this is reflected in their effort to maintain segregation in buying products and services. Religious symbols being the emblem of religious traditions are important hallmark of every faith. Depending on the level of affiliation with a particular faith, religious symbols vary in importance to the followers of that faith. Level of belief or religiosity in a particular tenet is the religious dogmatism of individuals in the society (Giuseppe 1981). Religious dogmatism has positive correlation with the religiosity or meaning a person associates with a religion. Therefore, religious symbols are more significant for the individuals who posses greater religious inclination such as a cross can spawn a favorable association in the minds of Christians similarly mosque is a sacred symbol for the followers of Islam. These religious symbols elicit favorable image in the minds of respective disciples.

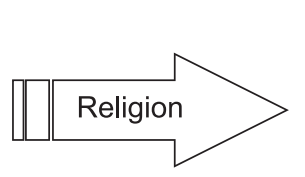

Figure 1: Value System

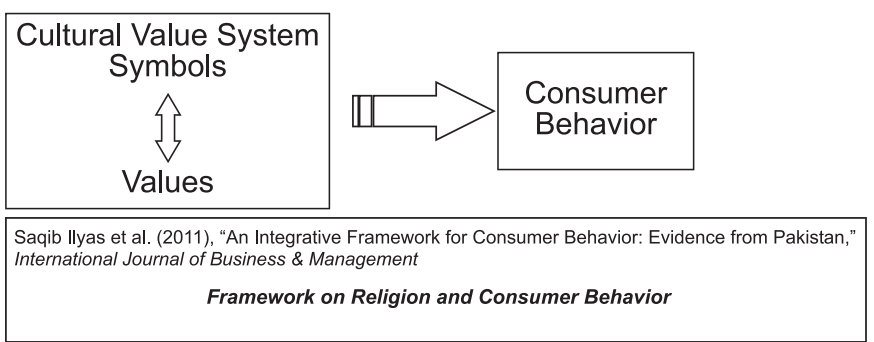

\begin{tabular}{l|llll}
\hline 36 & July 2012 & Volume 10 & Number 2 & JISR-MSSE
\end{tabular}


Studies on consumer behavior have shown that peripheral cues and messages in marketing communications stimulate attraction of target audience in advertisements. Attitude towards advertisements can be favorable or unfavorable depending upon the stimulus in an exposure (Solomon 1992, p. 139). The emphasis of advertisements is to create positive influence after the exposure. Research indicates that attitude towards advertisements can be divided into two broad dimensions (Shimp 1981; Burton \& Lichtenstein 1989). First is cognitive dimension in which consumer has to form an attitude towards an advertisement based on copy, caption and layout of the advertisement. The second is the emotional dimension in which consumer forms an attitude towards an advertisement because they have been stimulated by the effective response to an advertisement. This attitude is instrumental in creating a brand choice and minimizing purchase decision. Shimp (1981) suggested that a positive feeling towards an advertisement helps improve brand image and maximizes probability of purchasing brand.

Available literature suggests that discussion on offensiveness of advertisements is dispersed under topics such as offensive advertising (Aaker \& Bruzzone 1985; Bartos 1981; Li et al 2002; Waller 1999), advertisements aimed at special groups (Wood 1990; Zhang \& Shavitt 2003), shocking appeals (Dahl et al 2003), and feminist disparagement (Kilbourne 1990; Seger 1990; White 1990). Dahl et al (2003) propose that offensive advertising is the one that breaks the norms and values. It includes portrayal of anything that violates and transgresses the normally accepted values of the society. This includes vulgarity, profanity, and use of violence, spiritual symbols, and sexist images and anti-human rights.

Advertising has been under criticism from various researchers not only because of its intended impact on the society but unintended impact as well (Fullerton \& Nevett 1986). Earlier, critics on advertisements have been people from the high strata's and socioeconomic classes since inception of the marketing era, people belonging to middle class of the society have shown positive attitude towards advertisements (Bauer \& Greyser 1968; Fullerton \& Nevett 1986). Bauer and Greyser (1968) argued that advertising critics have failed to create mass consciousness on this issue and that: (a) advertising breeds materialism in the society by creating desire for unintended purchases; (b) advertising spawns an irrational behavior; (c) advertising idealizes unobtainable standard of living by its customers; (d) advertising appeals to individual selfishness and greed; (e) advertising deception and half-truth fosters deception culture and stereotypes; (f) it violates the sanctity of religious symbols and values; (g) advertising uses multiple appeals that cause physical and emotional disturbances among masses.

In order to compete for the consumer wallet of share merchandisers have offered multiple products and multiple versions of the same product and finally multiple means to market the product in a highly cluttered market. It means that consumers are constantly bombarded with advertisements and attractive messages. James Twitch Well, in his book Adcult said "only way to avoid advertisements is to go sleep". This assault by marketers and advertisers have taken the hold of consumer's life and convinced them to buy happiness by buying more of products and services. It is the marketers and advertisers that have convinced the consumers that they can buy a new body, inner peace of mind, salvation and more than that spirituality.

Research studies found that consumers pay attention to important details in the advertisement or commercial, they absorb this stimulus in the form of relevant associations, images and experiences in the memory and then draw inferences based upon analysis of the message from memory and advertising stimulus. This concept is the source of attitude towards an advertisement which can be defined as a "predisposition to respond to an advertisement favorably or unfavorably during an exposure" (Solomon 1992, p. 139). Attitude towards advertisements is a dependent

\begin{tabular}{llll|l}
\hline JISR-MSSE & Volume 10 & Number 2 & July 2012 & 37
\end{tabular}


variable in copy tests and emphasis is to spawn a positive attitude from the viewer. A consumer's attitude towards advertisements impact his/her decision for brand choice as it depends on an overall evaluation of each alternative and belief about the product choice.

Religious symbols and imagery differ in meaning and impact to a particular religious affiliation depending upon the level of affiliation with a particular faith. People having strong affinity with religion have more tendencies to like or dissuade an advertisement based on the level of attachment with the symbols of that religion and faith.

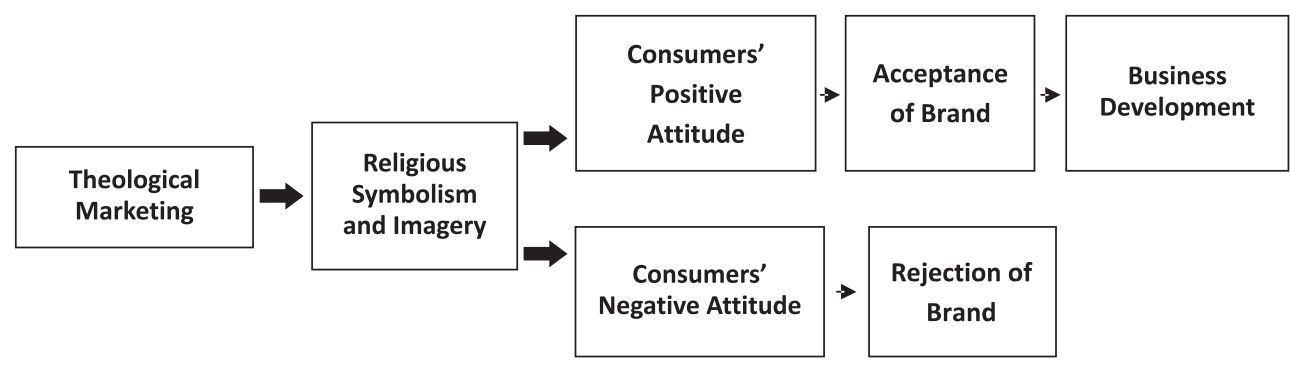

Figure 2: Conceptual Framework

Therefore, presence of concrete religious imagery is of more significance to those with greater religious inclination. This nature of advertising appeal is an important factor in determining the favorable and unfavorable attitude. Negative attitude towards an advertisement when coupled with decision of not to purchase a brand sometimes spawns unfavorable feelings that turn into offensive behavior. Consumers positively respond to advertisements that they find congruent with personal values and beliefs and reward those who tailor such advertisements that reflect their ideology. Religious affinity and orientation plays a crucial role in people's lives by shaping their attitudes, values, understanding and behavior towards society. Followers of different religions such as Muslims, Buddhists, Christians, Hindus and others have different perceptions and beliefs. It is not possible to escape from instilled beliefs and commitments which are reflected in people's attitude towards buying behavior. For instance, in USA, UK and Europe the consumption patterns and buying behavior of Asian community is different as compared to indigenous British population due to communal and religious commitment. It is off-course religion which defines boundaries for prohibited and allowed products and services. More precise impact of religion can be gauged through religiosity of an individual. Glock (1972) propound that religiosity has five dimensions: (i) Ideological (ii) Intellectual (iii) Ritualistic (iv) Consequential (v) Experimental.

Ideological aspect includes belief about religion, for instance, Muslims believe in one God and His Holy Messenger (PBUH), last day and resurrection etc. and so do Christians believe in Holy Trinity. Intellectual aspect of religiosity measures one's knowledge and understanding about his/her belief. The ritualistic dimension includes certain activities as prescribed by the religion such as Muslims offers prayers, fast during the Holy month of Ramadan, perform pilgrimage. Similarly, Christians have their own religious tenants to practice. Consequential dimension describes the vitality and importance of the religion, whereas experimental aspects proved the glimpse of the practicality of religion in one's life. Attitude of the respondents towards religious symbolism has been reconnoitered through following global and local advertisements.

\begin{tabular}{l|llll}
\hline 38 & July 2012 & Volume 10 & Number 2 & JISR-MSSE
\end{tabular}




\section{Research Design and Methodology}

This is a descriptive research study that uses quantitative research design which involves collecting data in form of numbers. Cross-sectional survey design that implies collecting information at one point in time is employed in research study, to this end; closed-ended questionnaire is administered to target respondents in two universities. Past studies suggests that university students classify as good subjects for research on consumer behavior. As no sampling frame is available, the purposeful sample, which implies intentionally selecting subjects or participants to learn and understand the phenomenon under study, has been employed. A convenience sample of 150 undergraduate and graduate students in class rooms of groups 30 to 50 were presented with seven advertisements ( 3 video and 4 print versions). After watching each advertisement twice, target respondents filled questionnaire related to corresponding advertisement. Approximately 140 questionnaires were collected. Out of 140, 26 questionnaires were discarded because many of the questions were not answered in those questionnaires. Therefore, only 112 questionnaires were used for data analysis. This represents response rate of 80 percent.

\section{Measuring Constructs}

The instrument measures two important constructs or sub parts i.e., customer perception (positive or negative) towards these advertisements and brand acceptance or rejection based on advertisements. Items of these sub parts are retrieved from previous research studies. 14 items set of adjectives are used to measure positive and negative perception towards these advertisements on 1 to 5 Likert scale, where 1 indicates highly disagree and 5 indicates highly agree. Positive and negative adjectives provide further insights on relationship among both measures. In all, items for seven advertisements (3 video and 4 print adverts) were included in the questionnaire and prior to their inclusion a small focus group of 6 participants was carried out to select the advertisements that were rich in religious imagery. After each advertisement respondents were asked about their intension of accepting or rejecting the brand based on the advertisement on 5 point Likert scale. Reliability of the items measuring the above-mentioned dimensions is established in literature as congruent study was carried out in China comparing attitude of Chinese and German buyers towards advertisements. Cronbach's alpha for 14 items is 0.634 ; the alpha value above 0.5 represents strong reliability.

\section{Results and Discussion}

Understanding of religious and cultural norms and values is pre-requisite for successful marketing and advertising campaigns. It is of prime importance to align marketing communication with established beliefs and attitudes. In order to explore underlying perceptions and attitude about religious iconography the survey was limited to given geographical boundaries.

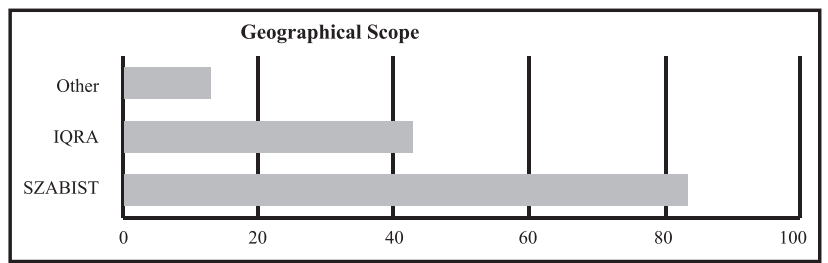

Figure 3: Geographical Scope

The respondents of study were both male and female representing five age groups. Majority of the respondents were young consumers in age bracket from 18 to 35 years.

\begin{tabular}{llll|l}
\hline JISR-MSSE & Volume 10 & Number 2 & July 2012 & 39
\end{tabular}




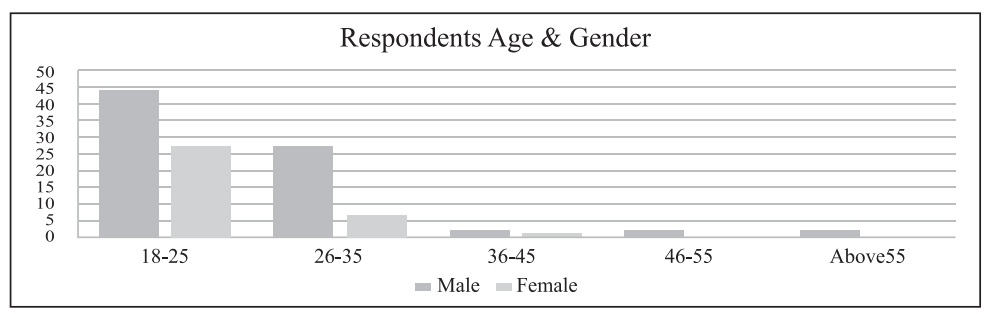

Figure 4: Respondents' Statistics

Reliability of the items measuring all above dimensions is established in literature as congruent study was carried out in China comparing attitude of Chinese and German buyers towards advertisements. Cronbach's alpha for 14 items is 0.634 ; the alpha value above 0.5 represents strong reliability.

Hypothesis 1: Religious acceptance of advertisements depends upon favorable attitude towards advertisements.

Table 1: Statistics

\begin{tabular}{|c|c|c|c|c|c|c|}
\hline \multirow[b]{3}{*}{ Religiously Acceptable1 } & \multicolumn{2}{|c|}{$\begin{array}{l}\text { Unstandardized } \\
\text { Coefficients }\end{array}$} & \multirow{2}{*}{$\begin{array}{c}\begin{array}{c}\text { Standardized } \\
\text { Coefficients }\end{array} \\
\text { Beta }\end{array}$} & \multirow[b]{2}{*}{$\mathrm{t}$} & \multirow[b]{2}{*}{ Sig. } & \multirow{2}{*}{$\begin{array}{l}\text { Empirical } \\
\text { Decision }\end{array}$} \\
\hline & B & Std. Error & & & & \\
\hline & 0.323 & 0.043 & 0.584 & 7.548 & 0 & Reject Ho \\
\hline Religiously Acceptable2 & 0.409 & 0.044 & 0.662 & 9.262 & 0 & Reject Ho \\
\hline Religiously Acceptable3 & 0.482 & 0.049 & 0.687 & 9.917 & 0 & Reject Ho \\
\hline Religiously Acceptable4 & 0.544 & 0.041 & 0.781 & 13.14 & 0 & Reject Ho \\
\hline Religiously Acceptable5 & 0.383 & 0.073 & 0.448 & 5.259 & 0 & Reject Ho \\
\hline Religiously Acceptable6 & 0.367 & 0.066 & 0.467 & 5.543 & 0 & Reject Ho \\
\hline Religiously Acceptable7 & 0.579 & 0.042 & 0.796 & 13.8 & 0 & Reject Ho \\
\hline
\end{tabular}

As Sig. value of $0.000<\boldsymbol{\alpha}=0.05$; reject all Ho in favor of alternate hypothesis, which means that two variables i.e., religious acceptability and favorable attitude are dependent. There is significant evidence to report that favorable attitude depends on religious acceptability of the content in advertisement.

\begin{tabular}{l|llll}
\hline 40 & July 2012 & Volume 10 & Number 2 & JISR-MSSE
\end{tabular}


Hypothesis 2: Inclusion of religious symbols and imagery in advertisements leads to the rejection of brands.

Table 2 : Statistics

\begin{tabular}{|c|c|c|c|c|c|c|}
\hline \multirow[b]{3}{*}{ Religiously Acceptable1 } & \multicolumn{2}{|c|}{$\begin{array}{c}\text { Unstandardized } \\
\text { Coefficients }\end{array}$} & \multirow{2}{*}{$\begin{array}{c}\begin{array}{c}\text { Standardized } \\
\text { Coefficients }\end{array} \\
\text { Beta }\end{array}$} & \multirow[b]{2}{*}{$\mathrm{t}$} & \multirow[b]{2}{*}{ Sig. } & \multirow{2}{*}{$\begin{array}{l}\text { Empirical } \\
\text { Decision }\end{array}$} \\
\hline & B & Std. Error & & & & \\
\hline & 0.401 & 0.136 & 0.271 & 2.955 & 0 & Reject Ho \\
\hline Religiously Acceptable 2 & 0.571 & 0.138 & 0.368 & 4.149 & 0 & Reject Ho \\
\hline Religiously Acceptable3 & 0.67 & 0.129 & 0.443 & 5.176 & o & Reject Ho \\
\hline Religiously Acceptable4 & 0.744 & 0.098 & 0.587 & 7.597 & o & Reject Ho \\
\hline Religiously Acceptable5 & 0.633 & 0.094 & 0.557 & 7.039 & o & Reject Ho \\
\hline Religiously Acceptable6 & 0.722 & 0.11 & 0.531 & 6.579 & o & Reject Ho \\
\hline Religiously Acceptable7 & 0.959 & 0.08 & 0.753 & 11.99 & 0 & Reject Ho \\
\hline
\end{tabular}

$\alpha=0.05$, which means that all null hypotheses are rejected in favor of alternative hypothesis. It can be infered that religious symbolism in advertisements is detested by audience and they may rebuke brands by not buying them

Statistic stable 4.3 summarizes the model fit and dependency of the variables, attitude towards religious symbolism and religious acceptance of religious iconography in advertisements. Model summarizes that 54.9 percent variation in attitude of consumers is explained by religious iconography. However, this is not only the predictor, attitude towards advertisements is explained by other variables which are beyond the scope of this research.

Table 3 : Statistics

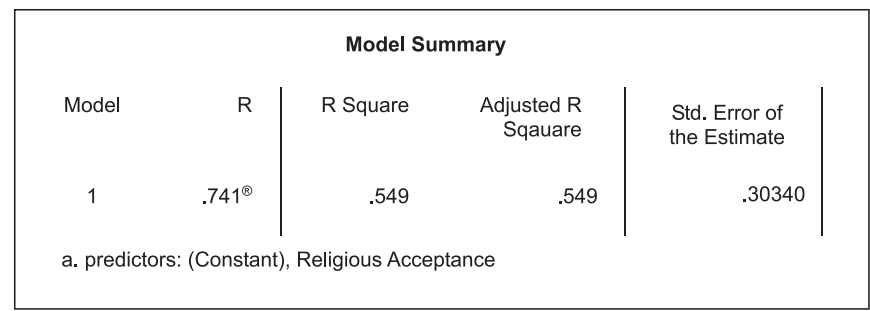

Theological references are made in the advertisements to buy share of mind of the people and promote sales. The research findings boil down to the point that extreme care should be taken in inclusion of religious symbols in advertisements. Sensitivities must be taken into account in multicultural societies. There must be a natural connection between the brand and religious content and if there is no relation at all then the use of religious symbolism in advertisements is sacrilegious and offensive. Respondents showed unfavorable attitude to the advertisements that contained extreme religious makeup for instance Name of Allah (SWT) and His Holy Prophet (PBUH), Quran, Bible, Cross and church.

Certain advertisements contain Holy symbols such as Cross, nun, priest, all concocted into sexual imagery which is deeply unacceptable as ice-cream brand does not have natural connection with the religious imagery. It is provocative blend of libido and religion which preaches submission to temptation; it is rated as highly unacceptable. An advertisement portrayed an Arabian Beauty whose beautiful hair turned into hijab. Such advertisement is religiously acceptable to the audience as it does not incorporate gross religious themes and ties. In fact, it is more interesting, clever and creative way of positioning brand persona. It seems very interesting and convincing

\begin{tabular}{llll|l}
\hline JISR-MSSE & Volume 10 & Number 2 & July 2012 & 41
\end{tabular}


to pay homage to Arabian beauty with hair so thick and shiny that it turns into hijab which is emblem of Islamic and Arabic heritage. A foreign brand advertisement positions French automotive brand Renault as quietest and portrays a Bible and service in church. Connection has been made between peace and silence in church and smoothness and peace of Renault engine. Bible is the Holy book of Christianity hence, majority of respondents did not like the idea of making connection between peace in church and of engine. Another advertisement which was taken as a case study is public service message by Novartis Pakistan to get vaccinated before going to Haj or Umrah as per the requirement of government of Saudi Arabia. As most of the pilgrims do not get vaccinated and produce fake medical certificates hence brand has employed religious scholar who preaches not to start a holy journey with a lie of not getting vaccinated.

This research finds that it is not a good idea to pitch a brand with a tagline that religiously emotionalizes the audiences by employing a well reputed religious scholar. Another advertisement portrays the holy month of Ramadan; rich Islamic symbols and Holy Names of Allah (SWT) and His Messenger (PBUH) and His companion Hazrat Ali (RTA). Respondents found this advertisement as offensive and sacrilegious. Moreover, there is no connection between the message of brand which focuses on free talk time and religious imagery and wordings. Another advertisement features Angelic models and holy symbols of Christianity. Although this is rated as creative and convincing yet majority of the respondents does not favor the idea of using religious symbols and sexual imagery together. Similarly, another advertisement celebrates the arrival of holy month Ramadan and portrays Islamic harmony, this advertisement has been highly convincing, lively, creative and religiously acceptable to the audiences. Brand is successful in finding a knot between brand persona and religious imagery and symbolism. It features religious images in a decent way and is rated as highly acceptable amongst all advertisements.

\section{Conclusion}

To conclude, based upon the findings of the study, it can be said that presence of religious imagery does not only generate a marginal stimulus but affects the image of the brand in mind of prospective buyers and consumers. Basic tenets of faith and associated sensitive religious imagery must not be imbued in advertisements but with utmost care and audit. Moreover, there should be a logical nexus between brand persona and inclusion of religious symbols. In case of a strong disconnect, advertisement may spread a word of mouth for a while but ultimately repels the audience. The results of research study are of extreme importance to companies, their products and services and their advertising agencies that plan and execute campaigns for clients. It is, therefore, imperative to produce commercials that do not contravene religious perceptions of target market.

\section{References}

Aaker, DA \& Bruzzone, DE 1985, "Causes of irritation in advertising”, Journal of Marketing, vol. 49 , no. 2 , pp. $47-57$.

Abernethy, MA \& Franke, GR 1996, "The information content of advertising: a meta-analysis", Journal of Advertising, vol. 25, no. 2, pp. 1-17.

Bauer, R \& Greyser, S 1968, Advertising in America: The Consumer View, Harvard University Press, Boston.

\begin{tabular}{l|llll}
\hline 42 & July 2012 & Volume 10 & Number 2 & JSRR-MSSE
\end{tabular}


Bartos, R 1981, "Ads that irritate may erode trust in advertised brands", Harvard Business Review, July/August, pp. 138-139.

Burton, S \& Lichtenstein, D 1988, "The effect of ad claims and ad content on attitude toward the advertisement", Journal of Advertising, vol. 17, issue 1, pp. 3-11.

Clifford, G 1973, The Interpretation of Cultures, Basic Books, New York.

Dahl, DW, Frankenberg, KD \& Manchandra, RV 2003, "Does it pay to shock? Reactions to shocking and non-shocking advertising content among university students", Journal of Advertising Research, vol. 43, no. 3, pp. 268-80.

Finke, R, \& Iannaccone, LR 1993., "Supply-side explanations for religious change", Annals of the American Academy of Political and Social Science, vol. 527, pp. 27-39.

Fullerton, R 1988, "How modern is modern marketing? Marketing's evolution and the myth of the production era," Journal of Marketing, vol. 52, no. 1, pp. 108-125.

Geier, P 1986, “Global products, localized messages”, Marketing Communication, vol. 11, pp. 23-27.

Giuseppe, RAD 1981, "Dogmatism correlation with strength of religious conviction", Psychological Reports, vol. 28, no. 1, p. 64.

Gottdiener, M 1985, "Hegemony and mass culture: a semiotic approach", American Journal of Sociology, vol. 90, no. 5, pp. 979-1001.

Gökariksel, B \& Secor, A 2010, "Between fashion and tesettür: marketing and consuming women's Islamic dress", Journal of Middle East Women's Studies, vol. 6, no. 3, pp. 118-148.

Harrell, GD 1986, Consumer Behavior, Harcourt, Brace, Jovanovich Publishers, San Diego.

Herm, S 2011, "Two routes to brand recognition in product design: a new method to examine explicit and implicit cues", 40 th European Marketing Conference, Ljubljana, Slovenia.

James, CN 1964, A History of Islamic Law, Edinburgh University Press, Edinburgh.

Kaplan, R 1994, “Ad agencies take on the world”, International Management, vol. 49, no. 3, p. 50.

Kilbourne, J 1990,'Beauty . . . and the beast of advertising”, Media \& Values, vol. 49, available from: www.medialit.org/reading_room/article40.html

Levitt, T 1983, “Globalization of markets”, Harvard Business Review, May-June, pp. 92-102.

Levy, SJ 1959, “Symbols for sale”, Harvard Business Review, July- August, pp. 117-124.

Levy, SJ 1989, "Symbols, selves, and others”, Advances in Consumer Research, vol. 9, pp. 542-543.

Luqmani, M, Yugur, Y, \& Quraeshi, Z 1987, “Advertising in Saudi Arabia: Content and Regulation”, International Marketing Review, vol. 6, no. 1, pp. 59-72.

\begin{tabular}{llll|l}
\hline JISR-MSSE & Volume 10 & Number 2 & July 2012 & 43
\end{tabular}


Mallia, KL 2009, "From the sacred to the profane: a critical analysis of the changing nature of religious imagery in advertising", Journal of Media and Religion, vol. 8, no. 3, p. 172.

Mohandass, D, Sinha, S \& Varma, U 2006, "Use and Effectiveness of Religious Symbology in Advertising", Symbiosis Institute of Management, Pune, available from:

http://www.sibm.edu/FacultyResearch/pdf/srp/marketing/SRP_Effectiveness_and_use_of_Rel igious_symbols.pdf

Seybert, J 2004, EPM's Guide to the Christian Mmarketplace: Selling Books, Music, Gifts and Videos to America's 218 million Christians, EPM Communications, New York.

Shimp, TA 1981, "Attitude toward the ad as a mediator of brand choice", Journal of Advertising, vol. 10, pp. 9-15.

Solomon, MR, "The role of products as social stimuli: a symbolic interactionisim perspective", Journal of Consumer Research, vol. 10, pp. 319-329.

Treise, D, Weigold, MF, Conna, J \& Garrison, H 1994, "Ethics in advertising: ideology correlates of consumer perceptions", Journal of Advertising, vol. 23, no. 3, pp. 59-69.

Wilson, A \& West, C 1981, “The marketing of unmentionables”, Harvard Business Review, January-February, pp. 91-102.

Wood, RE 1990, "Attacking ageism in advertising: at AARP, senior stereotypes give way to active advertising”, Media \& Values, vol. 45, available from: www.medialit.org/reading room/article523.html

Zhang, Y \& Betsy, G 1996, "Matching Advertising Ap-peals to Culture: The Influence of Product Use Conditions", Journal of Advertising, vol. 25, pp. 29-46. 